E-ISSN : 2527-712x

Vol.6 (no.2) Desember 2021

Jurnal Analis Laboratorium Medik

Avalilable Online http://e-journal.sari-mutiara.ac.id/index.php/ALM

\title{
GAMBARAN KADAR ASAM URAT PADA PASIEN TUBERKULOSIS PARU SENSITIF OBAT SETELAH PENGOBATAN FASE INTENSIF DI PUSKESMAS KECAMATAN KRAMAT JATI
}

\author{
Nicolaus Sri Widada, Ayuningtias Wulandari \\ Program Studi DIV Teknologi Laboratorium Medik Universitas Binawan \\ Email :nicolaus@binawan.ac.id \\ Program Studi DIV Teknologi Laboratorium Medik Universitas Binawan \\ Email :ayuningtysn@gmail.com
}

\begin{abstract}
ABSTRAK
Pengobatan tuberkulosis yang menggunakan prinsip multidrugs dengan waktu pengobatan yang lama sering menimbulkan berbagai efek samping. Peningkatan kadar asam urat darah diduga salah satu efek sampingnya. Pirazinamid dan etambutol merupakan obat yang disinyalir dapat menyebabkan peningkatan kadar asam urat di dalam tubuh.Tujuan penelitian ini adalah mengetahui karakteristik pasien tuberkulosis paru sensitif obat berdasarkan jenis kelamin dan usia, rata-rata kadar asam urat pasien tuberkulosis paru sensitif obat setelah pengobatan fase intensif, dan persentase pasien TB paru sensitif obat yang mengalami peningkatan kadar asam urat. Jenis penelitian deskriptif kuantitatif dengan teknik pengumpulan data secara cross sectionaldan teknik consecutive sampling. Penelitian ini dilakukan di Puskesmas Kecamatan Kramat Jati Jakarta Timur. Dari penelitian diperolahhasil :rata-rata kadar asam urat darah pasien TB paru sensitif obat 7,4 $\pm 2,84 \mathrm{mg} / \mathrm{dl}$ (mean \pm SD) dengan kadar terendah 3,5 mg/dl dan kadar tertinggi 11,8 mg/dl. Jika dikelompokkan berdasarkan nilai rujukan, diperoleh data pasien TB paru sensitif obat dengan kadar asam urat yang mengalami peningkatan sebanyak 54,5\% dengan proporsi tertinggi pada kelompok usia $\geq 55$ tahun (100\%). Berdasarkan data tersebut untuk pasien TB Paru yang sedang menjalani terapi obat anti tuberkulosis (OAT)diharapkan mengurangi asupan makanan tinggi purin (daging sapi, jeroan, makanan laut, alkohol, durian, kacang-kacangan) serta rutin melakukan medical check up secara berkala.
\end{abstract}

Kata Kunci : asam urat, tuberkulosis paru, sensitif obat, fase intensif, obat anti tuberkulosis

\begin{abstract}
Tuberculosis treatment that using multi-drugs principle with a long-time treatment period often causes side effects. One of the side effects is increasing of uric acid levels. Pyrazinamide and ethambutol are medicines that increase uric acid levels in the body. The purpose of this research was to determine characteristics drugssensitive pulmonary TB patients based on gender and age, to determine the average of urid acid levels after intensive phase treatment and to determine percentage of the drugs-sensitive pulmonary TB patients that have increasing uric acid levels at the Kramat Jati District Health Center. The type of this study is quantitative descriptive with cross sectional data collection techniques and consecutive sampling technique. The results of the statistical distribution of the mean blood uric acid levels in drug-sensitive pulmonary TB patients were 7.4 $\pm 2.84 \mathrm{mg} / \mathrm{dl}$ (mean $\pm S D$ ) with the lowest level of $3.5 \mathrm{mg} / \mathrm{dl}$ and the highest level of $11.8 \mathrm{mg} / \mathrm{dl}$. If it grouped by reference value, data obtained from drug-sensitive pulmonary TB patients with uric acid levels increased by $54.5 \%$ with the highest proportion in the age group $\geq 55$ years (100\%). Suggestions for pulmonary $T B$ patients who are undergoing anti tuberculosis drugs (ATDs) therapy are expected to reduce the intake of high-purine foods and routinely do medical check-up.
\end{abstract}

Keywords: uric acid, drug-sensitive, pulmonary TB patients

Universitas Sari Mutiara Indonesia

DOI: https://doi.org/10.51544/jalm.v6i2.2392 
Nicolaus Sri Widada et. all | Gambaran Kadar Asam Urat Pada Pasien Tuberkulosis Paru Sensitif Obat Setelah Pengobatan Fase Intensif di Puskesmas Kecamatan Kramat Jati

\section{PENDAHULUAN}

Tuberkulosis paru atau biasa disebut TB paru merupakan infeksi penyakit menular disebabkan oleh bakteri Mycobacterium tuberculosis. Bakteri ini menyerang paru-paru, dan dapat menyerang organ lain. ${ }^{1}$ Infeksi tuberkulosis ini mudah menular karena penyebarannya melalui percikan dahak (droplet nuclei) infeksius yang terhirup masuk ke saluran napas. ${ }^{2}$

Tuberkulosis merupakan satu dari 10 penyebab kematian. ${ }^{3}$ Di dunia, Indonesia berada diperingkat ketiga dunia setelah India dan China. ${ }^{4}$ Prevalensi tuberkulosis di Indonesia pada tahun 2018 sebanyak 842.000 kasus per 1 mei 2019 dan mengalami peningkatan pada tahun 2019 menjadi 845.000 kasus per 20 maret 2020. ${ }^{3}$ Berdasarkan data Profil Kesehatan Provinsi DKI Jakarta Tahun 2018, jumlah kasus TB paru mencapai 67.433 kasus, dengan kasus tertinggi di Jakarta Timur sebanyak 11.537 kasus. Infeksi TB Paru dapat menyerang hampir segala usia, selain usia infeksi ini juga dapat menyerang segala jenis kelamin.

Diagnosa tuberkulosis dilakukan dengan pemeriksaan fisik, pemeriksaan radiologi, dan pemeriksaan laboratorium. Salah satu pemeriksaan laboratorium penunjang adalah pemeriksaan darah rutin, termasuk pemeriksaan Laju Endap Darah ${ }^{1}$. Pemeriksaan ini juga dilakukan dalam rangka monitoring pemberian obat anti tuberkulosis (OAT) kepada pasien TB Paru yang diberikan dalam waktu hinggga 6 bulan. .

Pasien TB paru sensitif obat adalah infeksi TB paru yang dimana bakteri Mycobacterium tuberculosis masih sensitif terhadap obat anti tuberkulosis lini pertama. Pasien TB paru sensitif obat biasanya akan menerima pengobatan dengan setidaknya 4 jenis obat anti tuberkulosis (OAT) dalam bentuk kombinasi dosis tetap (KDT) dengan jangka waktu pengobatan minimal 6 bulan menggunakan panduan sesuai dengan upaya yang telah dilakukan Program Nasional Pengendalian TB untuk menanggulangi TB dengan strategi DOTS (Directly Observed Treatment Shortcourse). ${ }^{6,7}$

Universitas Sari Mutiara Indonesia

DOI: https://doi.org/10.51544/jalm.v6i2.2392
Pengobatan tuberkulosis yang menggunakan prinsip multidrugs dengan waktu pengobatan yang lama sering menimbulkan berbagai efek samping. Efek OAT dapat memicu kerusakan sel-sel hati secara kronis dan atau kerusakan kolestatis hati akibat gangguan aliran empedu ${ }^{2}$. Salah satu efek samping lainnya berupa peningkatan kadar asam. Pirazinamid dan etambutol merupakan obat yang menyebabkan peningkatan kadar asam urat di dalam tubuh.

Di dalam tubuh, asam urat merupakan senyawa normal sebagai akhir dari metabolisme purin. Hasil metabolisme dari purin akan dibawa ke hati, lalu mengalami oksidasi menjadi asam urat. ${ }^{8}$ Sebagian besar asam urat larut dalam darah, kemudian masuk ke ginjal dan dikeluarkan melalui urin. Kadar asam urat dapat diketahui melalui hasil pemeriksaan darah. ${ }^{9}$ Kadar asam urat normal di dalam darah yaitu laki-laki $3,4-7,0 \mathrm{mg} / \mathrm{dl}$ sedangkan pada perempuan 2,4 - 5,7 mg/dl.Penelitian yang dilakukan David et al. (2018) di Kamerun, menyatakan bahwa kadar asam urat di dalam darah pada pasienTB paru yang menjalani terapi OAT dengan lama pengobatan $\leq 2$ bulan mengalami peningkatan sebesar $69,8 \%$ dari 96 pasien, namun tidak terdapat penjelasan apakah subyek penelitian memiliki kelainan metabolisme asam urat sebelum positif tuberkulosis. Penelitian yang dilakukan Kondo et al. (2014-2015) di Manado, menyatakan bahwa kadar asam urat di dalam pada pasien TB paru yang menjalani terapi OAT mengalami peningkatan sebesar $60 \%$ dari 15 pasien, namun tidak terdapat penjelasan mengenai lamanya pengobatan.

Penelitian yang dilakukan oleh Syahida et al. (2019) di Makassar, menyatakan bahwa kadar asam urat di dalam darah pada pasien TB paru yang menjalani terapi OAT mengalami peningkatan sebesar $60 \%$ dari 30 sampel, namun tidak terdapat penjelasan mengenai lamanya pengobatan dan penjelasan apakah subyek penelitian memiliki kelainan metabolisme asam urat sebelum positif tuberkulosis. Berdasarkan uraian tersebut diatas, maka akan dilakukan penelitian lebih 
Nicolaus Sri Widada et. all | Gambaran Kadar Asam Urat Pada Pasien Tuberkulosis Paru Sensitif Obat Setelah Pengobatan Fase Intensif di Puskesmas Kecamatan Kramat Jati

lanjut terhadap kadar asam urat di dalam darah pada pasien tuberkulosis paru setelah pengobatan fase intens.

\section{METODOLOGI PENELITIAN}

Penelitian ini merupakan penelitian deskriptif kuantitatif dengan menganalisis kadar asam urat pada pasien TB paru setelahpengobatan fase intensif. Variabel dalam penelitian ini meliputi Pasien TB paru sensitif obat yang menjalani pengobatan fase intensif sebagai variabel dependen (variabel terikat) dan Kadar asam urat di dalam darah sebagai variabel independen (variabel bebas).

\section{HASIL DAN PEMBAHASAN}

Penelitian ini merupakan penelitian yang menggambarkan kadar asam urat pada pasien tuberkulosis paru sensitif obat setelah pengobatan fase intensif yang dilakukan di Puskesmas Kecamatan Kramat Jati sejak bulan Juni - Agustus 2020. Pada penelitian ini subyek yang dipilih yaitu pasien yang sedang menjalani pengobatan fase intensif di Puskesmas Kecamatan Kramat Jati pada bulan April - Juni 2020.

\section{Karakteristik Pasien TB Paru Sensitif Obat}

Dari 22 pasien TB Paru sensitif obat di Puskesmas Kecamatan Kramat Jati, bila didistribusikan berdasarkan usia dan jenis kelamin diperoleh data sebagai berikut

\section{\& Laki-laki : Perempuan}

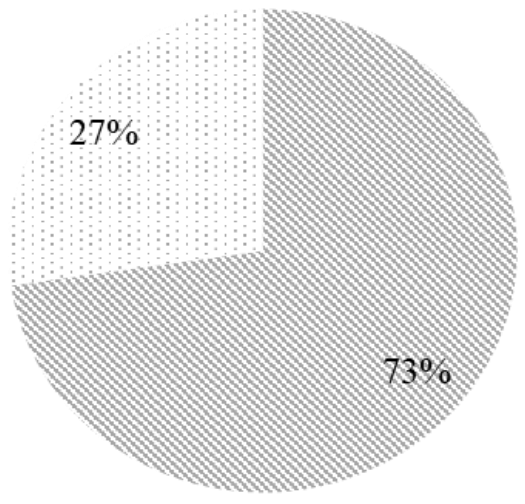

Gambar 1. Karakteristik pasien TB paru sensitif obat berdasarkan jenis kelamin

Karakteristik pasien TB paru sensitif obat yang dalam berpartisipasi penelitian ini dapat dilihat pada tabel 4.2. Penelitian ini memperoleh data bahwa jenis kelamin laki-laki lebih banyak dari perempuan.
Pasien TB paru sensitif obat laki-laki berjumlah 16 orang, sedangkan pasien TB paru sensitif obat perempuan berjumlah 6 orang. 
Nicolaus Sri Widada et. all | Gambaran Kadar Asam Urat Pada Pasien Tuberkulosis Paru Sensitif Obat Setelah Pengobatan Fase Intensif di Puskesmas Kecamatan Kramat Jati

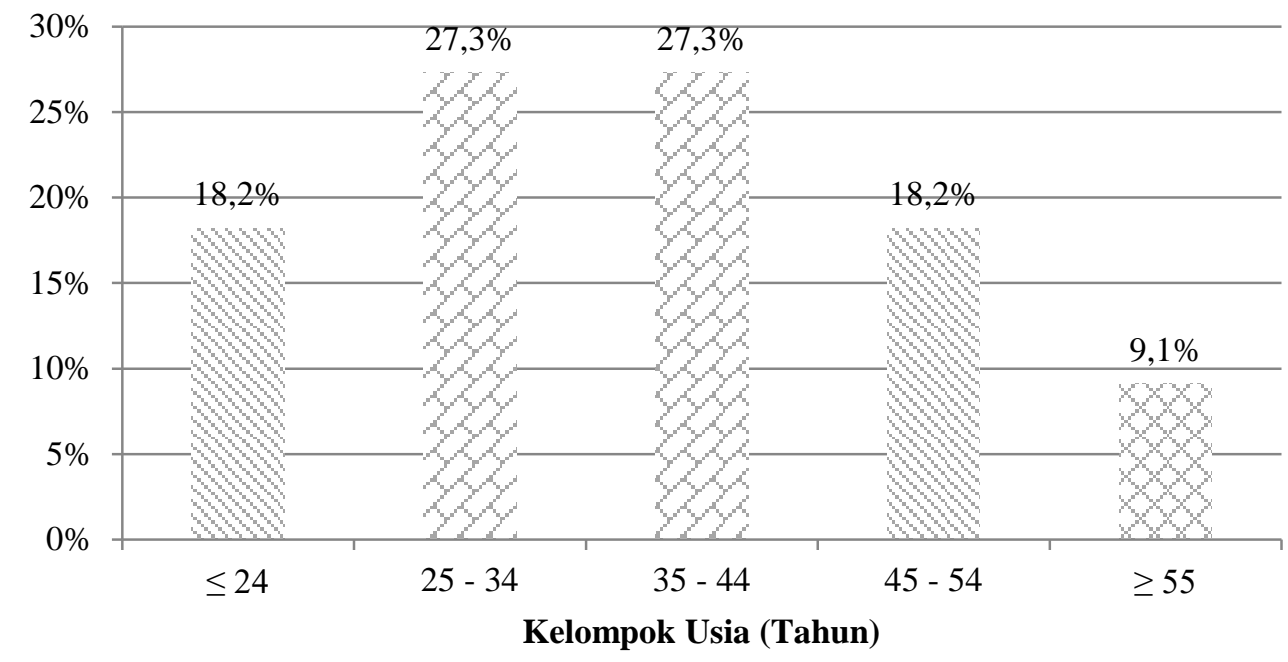

Gambar 2. Karakteristik pasien TB paru sensitif obat berdasarkanusia

Jika dikelompokkan berdasarkan usia, diperoleh data kelompok usia $\leq 24$ tahun sebanyak 4 orang $(18,2 \%)$, kelompok usia 25 - 34 tahun sebanyak 6 orang $(27,3 \%)$, kelompok usia 35 - 44 tahun sebanyak 6 orang $(27,3 \%)$, kelompok usia 45 - 54 tahun sebanyak 4 orang $(18,2 \%)$, kelompok, kelompok usia $\geq 55$ tahun sebanyak 2 orang $(9,1 \%)$.

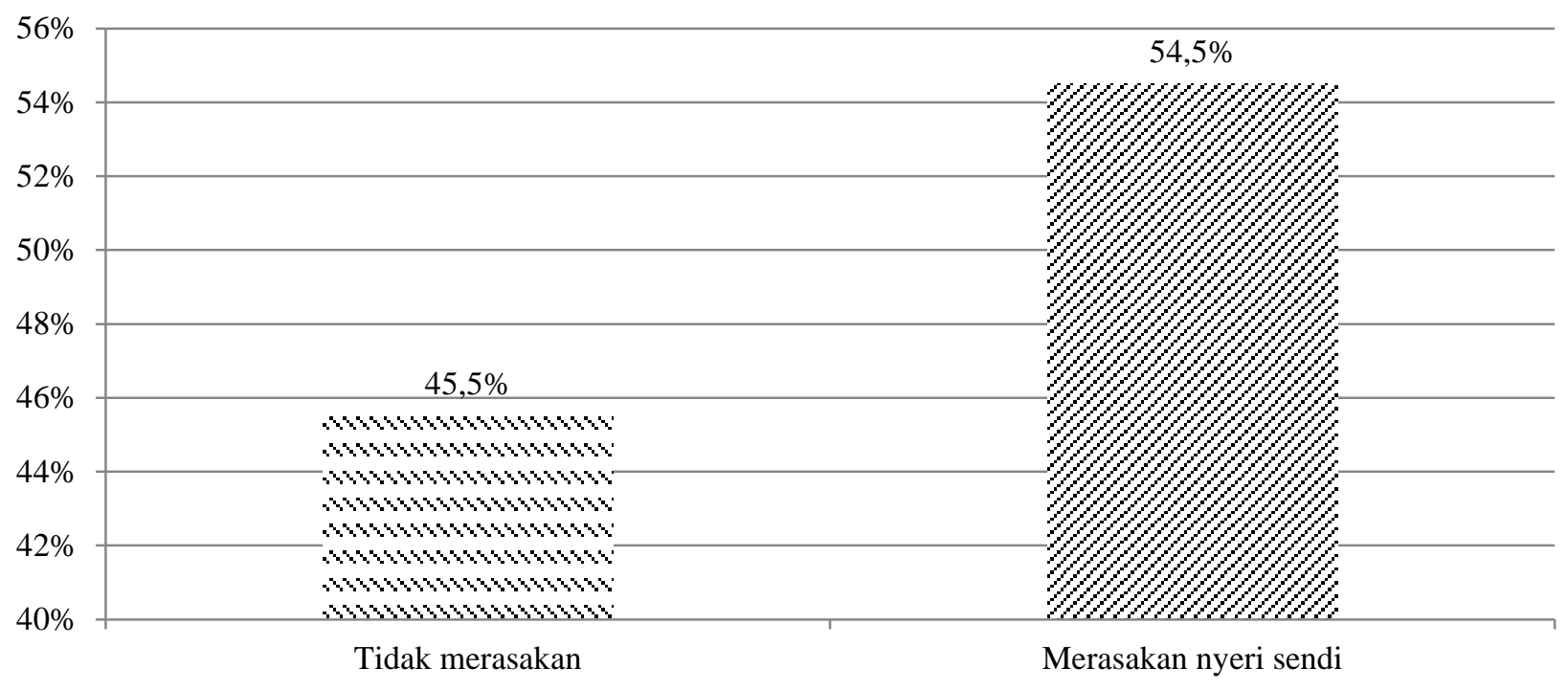

Gambar 3. Persentase Keluhan Nyeri Sendi Pasien TB Paru Sensitif Obat Setelah Pengobatan Fase Intensif

Berdasarkan Gambar 3, diperoleh data hasil wawancara dari 22 pasien TB paru sensitif obat yang berpartisipasi dalam penelitian ini $54,5 \%$ merasakan keluhan nyeri di bagian sendi. 
Nicolaus Sri Widada et. all | Gambaran Kadar Asam Urat Pada Pasien Tuberkulosis Paru Sensitif Obat Setelah Pengobatan Fase Intensif di Puskesmas Kecamatan Kramat Jati

Tabel 1.

Distribusi Frekuensi Konsumsi

Makanan Pasien TB Paru Sensitif Obat

Setelah Pengobatan Fase Intensif

\begin{tabular}{ccc}
\hline & n & \% \\
\hline $\begin{array}{c}\text { Mengonsumsi } \\
\text { Tinggi Purin }\end{array}$ & 10 & 45,5 \\
$\begin{array}{c}\text { Tidak Mengonsumsi } \\
\text { Tinggi Purin }\end{array}$ & 12 & \\
& & \\
& & \\
\hline
\end{tabular}

Dari 22 subyek penelitian, jika dikelompokkan berdasarkan pola konsumsi makanan, khususnya yang terkait dengan tinggi purin seperti jeroan, seafood, kacang-kacangan, hasil yang diperoleh data sebanyak $45,5 \%$ subyek yang mengonsumsi tinggi purin.

\section{Distribusi Kadar Asam Urat Pasien TB Paru Sensitif Obat Setelah Pengobatan Fase Intensif}

Pasien TB paru sensitif obat di Puskesmas Kecamatan Kramat Jati dilakukan pemeriksaan laboratorium asam urat darah setelah 2 bulan pertama pemberian obat anti tuberkulosis. Hasil yang diperoleh dapat dilihat pada tabel berikut :

Tabel 2.

Distribusi Kadar Asam Urat Pada Pasien TB Paru Sensitif Obat Setelah Pengobatan Fase Intensif

\begin{tabular}{lccccc}
\hline Variabel & n & Mean & SD & Min & Max \\
\hline $\begin{array}{l}\text { Kadar } \\
\text { Asam Urat } \\
(\mathrm{mg} / \mathrm{dl})\end{array}$ & 22 & 7,4 & 2,84 & 3,5 & 11,8 \\
& & & & & \\
\hline
\end{tabular}

Berdasarkan tabel 2 diperoleh data dari 22 subyek yang dianalisa didapatkan rata-rata kadar asam urat pada pasien TB paru sensitif obat setelah pengobatan fase intensif di Puskesmas Kecamatan Kramat Jati adalah 7,4 $\pm 2,84 \mathrm{mg} / \mathrm{dl}$ (mean $\pm \mathrm{SD}$ ) dengan kadar

Universitas Sari Mutiara Indonesia

DOI: https://doi.org/10.51544/jalm.v6i2.2392 terendah 3,5 mg/dl dan kadar tertinggi 11,8 $\mathrm{mg} / \mathrm{dl}$.

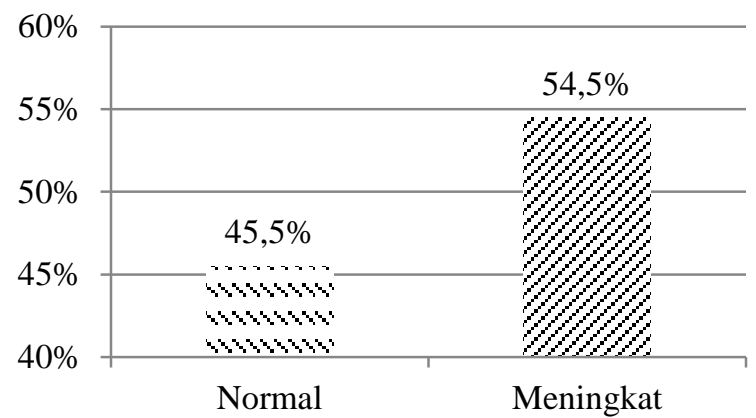

Gambar 4. Persentase Kadar Asam Urat Darah Pada Pasien TB Paru Sensitif Obat Setelah Pengobatan Fase Intensif

Apabila dikelompokkan berdasarkan nilai rujukan, diperoleh data pasien $\mathrm{TB}$ paru sensitif obat dengan kadar asam urat yang mengalami peningkatan sebanyak $54,5 \%$, dan kadar asam urat normal sebanyak $45,5 \%$.

Tabel 3

Distribusi Kadar Asam Urat Berdasarkan Jenis Kelamin

\begin{tabular}{ccccc}
\hline \multirow{2}{*}{ Jenis } & \multicolumn{2}{c}{ Normal } & \multicolumn{2}{c}{ Meningkat } \\
\cline { 2 - 5 } Kelamin & $\mathbf{n}$ & $\%$ & $\mathbf{n}$ & $\%$ \\
Laki-laki & 8 & 50 & 8 & 50 \\
Perempuan & 2 & 33,3 & 4 & 66,7 \\
\hline
\end{tabular}

Berdasarkan tabel 3 hasil pemeriksaan kadar asam urat dengan jenis kelamin lakilaki diperoleh 8 subjek (50\%) mengalami peningkatan kadar asam urat, dan 8 subyek lainnya (50\%) memiliki kadar asam urat dalam batas normal. Hasil pemeriksaan kadar asam urat dengan jenis kelamin perempuan diperoleh 4 orang subyek (66.7\%) mengalami peningkatan kadar asam urat, dan 2 subyek lainnya $(33,3 \%)$ memiliki kadar asam urat dalam batas normal. 
Nicolaus Sri Widada et. all | Gambaran Kadar Asam Urat Pada Pasien Tuberkulosis Paru Sensitif Obat Setelah Pengobatan Fase Intensif di Puskesmas Kecamatan Kramat Jati

Tabel 4

Distribusi Kadar Asam Urat Berdasarkan Usia

\begin{tabular}{ccccc}
\hline \multirow{2}{*}{ Usia } & \multicolumn{2}{c}{ Normal } & \multicolumn{2}{c}{ Meningkat } \\
\cline { 2 - 5 }$\leq 24$ tahun & 1 & 25 & 3 & 75 \\
25 - 34 tahun & 3 & 50 & 3 & 50 \\
$35-44$ tahun & 4 & 66,7 & 2 & 33,3 \\
$45-54$ tahun & 2 & 50 & 2 & 50 \\
$\geq 55$ tahun & 0 & 0 & 2 & 100 \\
\hline
\end{tabular}

Apabila kadar asam urat didistribusikan berdasarkan usia, maka diperoleh data yang dapat dilihat pada tabel 4.3.2, dimana padakelompok usia $\leq 24$ tahun diperoleh 3 subyek (75\%) yang mengalami peningkatan kadar asam urat, dan 1 subyek lainnya (25\%) memliki kadar asam urat dalam batas normal, kemudian pada kelompok usia 25 - 34 tahun diperoleh 3 subyek (50\%) yang mengalami peningkatan kadar asam urat, dan 3 subyek lainnya (50\%) memliki kadar asam urat dalam batas normal, kemudian pada kelompok usia $35-44$ tahun diperoleh 2 subyek $(33,3 \%)$ yang mengalami peningkatan kadar asam urat, dan 4 subyek lainnya $(66,7 \%)$ memliki kadar asam urat dalam batas normal, kemudian pada kelompok usia 45 - 54 tahun diperoleh 2 subyek (50\%) yang mengalami peningkatan kadar asam urat, dan 2 subyek lainnya (50\%) memliki kadar asam urat dalam batas normal, kemudian pada kelompok usia $\geq 55$ tahun diperoleh 2 subyek (100\%) yang mengalami peningkatan kadar asam urat.Individu yang memiliki kadar asam urat normal diketahui menjaga pola hidup sehat dengan cara menghindari makanan yang mengandung purin seperti kerang kerangan, otak, hati, jantung, paru, ginjal, jeroan, ekstrak daging/kaldu, daging angsa, burung dara, daging bebek, telur ikan, ikan sarden, remis, ikan herring, makarel, alkohol, ragi (tape), dan makanan yang diawetkan/ kalengan. ${ }^{3}$

\section{KESIMPULAN}

Berdasarkan hasil penelitian mengenai gambaran kadar asam urat darah pada pasien tuberkulosis paru sensitif obat setelah pengobatan fase intensif di Puskesmas Kecamatan Kramat Jati diperoleh beberapa kesimpulan :

1. Pasien TB paru sensitif obat laki-laki jumlahnya lebih dominan dibanding perempuan.Pasien TB paru sensitif obat laki-laki berjumlah 16 orang $(72,7 \%)$ sedangkan perempuan hanya 6 orang $(27,3 \%)$.

2. Angka kejadian tertinggi terjadi pada kelompok usia 25 - 34 tahun dan 35 44 tahun masing-masing berjumlah 6 orang $(27,3 \%)$

3. Dari 22 pasien TB paru sensitif obat, ditemukan $54,5 \%$ mengalami peningkatan kadar asam urat darah

4. Rata-rata kadar asam urat darah pasien TB paru sensitif obat 7,4 \pm $2,84 \mathrm{mg} / \mathrm{dl}($ mean $\pm \mathrm{SD})$ dengan kadar terendah $3,5 \mathrm{mg} / \mathrm{dl}$ dan kadar tertinggi $11,8 \mathrm{mg} / \mathrm{dl}$

\section{UCAPAN TERIMA KASIH}

Universitas Sari Mutiara Indonesia dan LPPM USM-Indonesia dan Puskesmas Kecamatan Kramat Jati.

\section{DAFTAR PUSTAKA}

Wiratma, D. Y. \& Situmorang, A. Pengaruh Perbedaan Metode Pemeriksaan Laju Endap Darah (Led) Terhadap Nilai Led Pasien Tersangka Penderita Tuberkulosis Paru Di Upt.Kesehatan Paru Masyarakat Dinas Kesehatan Provinsi Sumatera Utara Medan Tahun 2015. J. Anal. Lab. Med.1, 24-25 (2016).

Putri, W. R., Widada, S. T. \& Setiawan, B. Penurunan Kadar Bilirubin Total Serum 
Nicolaus Sri Widada et. all | Gambaran Kadar Asam Urat Pada Pasien Tuberkulosis Paru Sensitif Obat Setelah Pengobatan Fase Intensif di Puskesmas Kecamatan Kramat Jati

Yang Diencerkan Pada Penderita

Tuberkulosis. J. Anal. Lab. Med.6, 23-28

(2021).

Rajagukguk, T., Siahaan, M. A., Aritonang, E. \& Mutiara, U. S. Analisa Kadar Asam Urat Pada Wanita Menopause. 5, 1-4 (2020).

Nafila, Haqiqi R. N, Wahyunita S. Kadar asam urat pada pasien tuberkulosis dengan terapi obat anti tuberkulosis (OAT) di Puskesmas Cempaka Maret 2017. Jurnal Ilmiah Manuntung. 2017;3(2):174.

Kusumaningrum D, Koendhori EB, Mertaniasih NM. Buku Ajar Tuberkulosis Diagnostik Mikrobiologis. Surabaya : Pusat Penerbitan dan Percetakan UNAIR (AUP); 2013

Kementrian Kesehatan RI. Data dan Informasi Profil Kesehatan Indonesia 2018. Pusat Data dan Informasi Kementerian Kesehatan RI; 2019.

World Health Organization. Global Tuberkulosis Report 2019. The WHO Global TB Database; 2019.

Kementrian Kesehatan RI. Data dan Informasi Profil Kesehatan Indonesia 2017. Pusat Data dan Informasi Kementerian Kesehatan RI; 2017.

Pokam, B. D. T., Eeteneneng, E. J., Umoh, A., Umoh, N. O., \& Guemdjom, P. W. Uric acid levels in patients on antituberkulosis drugs in the Southwest region of Cameroon. International journal of mycobacteriology. 2018; 5, 89.

Departemen Kesehatan RI. Direktorat Bina Farmasi Komunitas Dan Klinik Direktorat Jenderal. Bina Kefarmasian dan Alat Kesehatan. 2005

Meilia, G. Kadar Asam Urat Pasien TB Paru Mendapat Tuberkulostatika. Doctoral dissertation. 2017
Martsiningsih, M. A., \& Otnel, D. Gambaran Kadar Asam Urat Darah Metode Basah (Uricase-PAP) Pada Sampel Serum dan Plasma EDTA. Jurnal Teknologi Laboratorium. 2016;5(1), 20-26.

Kementrian Kesehatan RI. Permenkes No. 67 Tahun 2016 tentang Penanggulangan Tuberkulosis. 2016

Indonesia, P. D. P. Tuberkulosis: pedoman diagnosis dan penatalaksanaan di Indonesia. Jakarta: PDPI. 2011, 20-30.

Aini, N., Ramadiani, R., \& Hatta, H. R. Sistem Pakar Pendiagnosa Penyakit Tuberkulosis. 2017

Safithri, F. Diagnosis TB Dewasa dan Anak Berdasarkan ISTC (International Srandard for TB Care). Saintika Medika: Jurnal Ilmu Kesehatan dan Kedokteran Keluarga. $2017 ; 7(2)$.

Davies PDO, Gordon SB, Davies G. Clinical Tuberkulosis. Ed. $5^{\text {th }}$. US: Taylor \& Francis; 2014

Kementrian Kesehatan RI. Petunjuk Teknis Manajemen dan Tatalaksana TB Anak. Jakarta ; 2016

Ganiswara, S. G. Farmakologi dan Terapi, edisi IV. Jakarta: Bagian Farmakologi Fakultas Kedokteran Universitas Indonesia; 1995.p802, 571, 572-573.

Katzung, B. G., Masters, S. B., \& Trevor, A. J. Farmakologi Dasar \& Klinik Vol. 2 Edisi 12. Jakarta : EGC;2014.

Mutschler, E. Dinamika Obat Farmakologi dan Toksikologi. Bandung: Penerbit ITB;1991

Diantari, E., \& Kusumastuti, A. C. Pengaruh Asupan Purin dan Cairan Terhadap Kadar Asam Urat Wanita Usia 50-60 Tahun di Kecamatan Gajah Mungkur, Semarang. Journal of nutrition college.2013;2(1), 44-49. 
Nicolaus Sri Widada et. all | Gambaran Kadar Asam Urat Pada Pasien Tuberkulosis Paru Sensitif Obat Setelah Pengobatan Fase Intensif di Puskesmas Kecamatan Kramat Jati

Verdiansah. Pemeriksaan Fungsi Ginjal. CDK-

237. 2016;43(2), 148-152

Lestari, E., Maryanto, S., \& Paundrianagari,

M. D. Hubungan konsumsi makanan sumber purin dengan kadar asam urat pada wanita usia 45-59 tahun di Desa Sanggrahan Kecamatan Kranggan

Kabupaten Temanggung.2017

Devkota, B. P. 5. Uric Acid: Reference Range, Interpretation, Collection and Panels [Internet]. Emedicine.medscape.com. 2012 [cited 21 January 2020]. Available from: http://emedicine.medscape.com/article/2088 516-overview\#showall

Nasrul, E., \& Sofitri, S. Hiperurisemia pada Pra Diabetes. Jurnal Kesehatan Andalas.2017;1(2).

Waring, W. S., Webb, D. J., \& Maxwell, S. R. J.Uric acid as a risk factor for cardiovascular disease. Qjm.2000;93(11), 707-713.

Spieker, L. E., Ruschitzka, F. T., Lüscher, T. F., \& Noll, G. The management of hyperuricemia and gout in patients with heart failure. European journal of heart failure. 2002; 4(4), 403-410.

Luk, A. J., \& Simkin, P. A. Epidemiology of hyperuricemia and gout. Am $J$ Manag Care.2015; 11(15 Suppl), S435-S442.

Qazi, Y. M. \& Lohr, J. W. M.6. Hyperuricemia: Background, Pathophysiology, Epidemiology [Internet]. Emedicine.medscape.com. 2012 [cited 11 January 2020]. Available from: http://emedicine.medscape.com/article/2417 67-overview\#a0104

Lingga, L. Bebas penyakit asam urat tanpa obat. AgroMedia.2012.

Nugraha, G., \& Badrawi, I. Pedoman Teknik Pemeriksaan Laboratorium Klinik Untuk
Mahasiswa Teknologi Laboratorium Medik.2018

Suryandari, N. Perbedaan Hasil Pemeriksaan Kadar Asam Urat Menggunakan Metode Spektrofotometri Dan Metode Strip.Doctoral dissertation.2017 